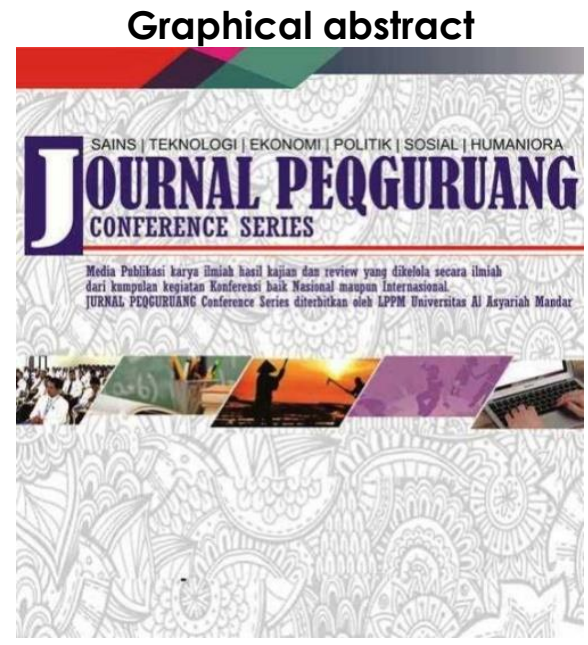

\title{
ANALISIS KEMAMPUAN MENULIS TEKS PROSEDUR PADA PESERTA DIDIK KELAS VIIA SMP NEGERI 1 POLEWALI
}

\author{
${ }^{1 *}$ Ayulestari, ${ }^{1 *}$ Chuduriah Sahabuddin ${ }^{1 *}$ Kurnia
}

*Universitas Al Asyariah Mandar

Ayulestari09031997@gmil.com

\begin{abstract}
This study aims to determine the ability to write procedure texts in grade VIIA Junior High School 1 Polewali students. This type of research used in this research is descriptive qualitative. The subjects of this study were 30th grade students of SMP Negeri 1 Polewali, totaling 30 students. The research instruments used in this study were test sheets, observation sheets, and interviews. Data collection techniques were namely test techniques, observation techniques, interview techniques, and documentation techniques. Data analysis with qualitative and quantitative techniques. The results of this study indicate that the VIIA grade students of SMP Negeri 1 Polewali obtain an average value of 86.8 with a percentage of $93.33 \%$ that is able to write procedure texts. In the aspect of content, it is in the very capable category with an average value of 27.37. In the structural aspect, it is in the very capable category with an average value of 19.07 . In the aspect of writing rules, it is in the category of being able with an average value of 14.37 and in the aspect of linguistic characteristics, it is in the category of being able with a value of 25.23 . Thus, it can be concluded that students of class VIIA of SMP Negeri 1 Polewali procedure text with an average value of 86.8 and the number of students reaching $75 \%$ who scored $75-100$.
\end{abstract}

Keywords: Writing, Text Procedure

\begin{abstract}
Abstrak
Penelitian tersebut bertujuan untuk mengetahui kemampuan menulis teks prosedur pada peserta didik kelas VIIA Smp Negeri 1 Polewali. Jenis penelitian yang digunakan dalam penelitian ini adalah deskriptif kualitatif. Subjek penelitian ini adalah siswa kelas VIIA SMP Negeri 1 Polewali yang berjumlah 30 orang siswa. Instrumen penelitian yang digunakan dalam penelitian ini yaitu lembar tes, lembar observasi, dan wawancara.Teknik pengumpulan data yaitu yaitu teknik tes, teknik observasi, teknik wawancara, dan teknik dokumentasi. Analisis data dengan teknik kualitatif dan teknik kuantitatif. Hasil penelitian ini menunjukkan bahwa siswa kelas VIIA SMP Negeri 1 Polewali memperoleh nilai rata-rata 86,8 dengan persentase $93,33 \%$ yaitu mampu menulis teks prosedur. Pada aspek isi, berada dalam kategori sangat mampu dengan nilai rata-rata 27,37. Pada aspek struktur, berada pada kategori sangat mampu dengan nilai rata-rata 19.07. Pada aspek kaidah penulisan, berada pada kategori mampu dengan nilai rata-rata 14,37 dan pada aspek ciri kebahasaan, berada dalam kategori mampu dengan nilai 25,23.Dengan demikian, dapat disimpulkan bahwa peserta didik kelas VIIA SMP Negeri 1 Polewali mampu dalam menulis teks prosedur dengan nilai rata-rata 86,8 dan jumlah peserta didik mecapai $75 \%$ yang memperoleh nilai 75-100.
\end{abstract}

Kata Kunci : Menulis, Teks Prosedur

\section{Article history}

DOI: http://dx.doi.org/10.35329/jp.v2i2.987

Received : 12 Agustus 2020 | Received in revised form : 3 September 2020 | Accepted :15 oktober 2020 


\section{PENDAHULUAN}

Pendidikan adalah komponen yang sangat dasar pada kehidupan. Dengan melaksanakan secara berancana dan sadar untuk membuat orang bangsa Indonesia dengan seutuhnya biar jadi menusia bependidikan, tebuka, pandai, inovatif, mandiri, dan bertanggung jawab merupakan pengertian dari pendidikan. Dengan memperkenalkan keterampilan cara menggunakan bahasa di sekolah yaitu dasar untuk mengembangkan gagasan dan perasan ke dalam bahasa secara lisan dan tulisan. Keterampilan menggunakan bahasa itu ada empat macam, yaitu menyimak, berbicara, membaca dan menulis.

Pembelajaran berbasis teks lebih ditekankan pada kurikukum 2013. Dengan bahasa yang mengatakan maksud dan tujuan secara konteks, sehingga pada pembelajaran teks tersebut, seorng siswa diarahkan agar bisa membuat dan mempergunkan teks sama dengan maksud dan tujuan sosialnya.

Dalman (2018:3) mengemukakan bahwa menulis adalah suatu tata dan cara berkomunikasi dengan penyampaian informasi secara tulis dan lisan kepada yang menggunakan bahasa pada saat proses komunikasi berlngsung. Ruang pendidikan formal sangat penting karena dengan hal tersebut, menulis bisa kita latih dengan secara sistematis dan gampang.

Teks prosedur sangatlah penting dikuasai seorang siswa, karena dengan hal tersebut ketika belajar maka teks itu merupakan suatu cara yang berisi tata dan cara untuk melaksanakan sesuatu biar bisa sngat mudah dan benar ketika mengerjakan tugas-tugas sekolah.

Alasan peneliti memilih SMP Negeri 1 Polewali: Pertama, SMPN 1 Polewali sudah menerapkan kuriklum 2013 Edisi Revisi. Kedua, di SMPN 1 Polewali peneltian mengenai menulis teks prosedur belum pernah dilakukan di sekolah tersebut. Berdasarkan uraian tersebut, serta latar belakang yang telah paparkan, maka peneliti akan mengadakan peneltian yang berjdul "Analisis Kemampuan Menulis Teks Prosedur Pada Peserta Didik Kelas VIIA SMP Negeri 1 Polewali”.

\section{Pembelajaran Bahasa Indonesia}

Haling (2007:14) mengemukakan bahwa pembelajaran tersebut adalah pekerjaan yang dilaksanakan secara terarah pada tiap tingkat-tingkat yaitu jadwal, terapan, dan menilai pembelajaran dan juga tindak lanjut. Menurut Sagala (2009:61) menyatakan bahwa pembelajaran merupakan kegiatan belajar seorang siswa untuk memanfaatkan pendidikan atau cara belajar yang sama penentu utama ketika sukses di kemudian hari.

\section{Keterampilan Menulis}

Keterampilan menulis adalah suatu jenis keterampilan berbahasa yang harys dikuasai seorang siswa. Keterampilan menulis itu menympaikan gagasan dan perasaan ketika diri berada dalam keadaan tertentu kepada orang lain dengan menggunkan bhasa sebagai media penympai informasi harus didukung dengan ketelitian penggunan kata yang dipergunkan (Abbas 2006:125).

Tarigan (2008: 3) mengemukakan bahwa keterampilan menulis adalah salah satu keahlian cara menggunakan bahsa yang mempergunakan dan melampaui yang bermanfat ketika komunikasi berlangsung secara tidk sengaja dan tidak bertatp muka dengan orang lain.

\section{Menulis}

Menulis adalah suatu keterampilan yang dimiliki manusia untuk dipergunakan dalam proses komunikasi dengan menyampaikan maksud dan tujuannya kepada orang lain (Tarigan 2013:3). Kegiatan membuat huruf menjadi suatu kalimat untuk dikomunikasikan kepaa pembaca atau kepada orang lain. Menulis ialah suatu kegiatan dengan menyampikan perasaan melalui kata sebagai media bahasanya agar bisa dimaknai dengan apa yang kita maksudkan kepada orang lain (Dalman 2018).

Kurnia (2019:107) mengemukakan bahwa menulis itu bisa menurunkn atau menggambarkan simbol atau lambang grafik yang dimiiki bahasa agar bis dipahami dengan baik oleh orang lain sehingga orang lain tersebut dapat membaca atau memaknai dngan apa yang kita maksudkan.

\section{Teks}

Halliday dan Ruqaiyah (dalam Mahsun 2014:1) mengemukakan bahwa teks adalah mengarah kepada hal-hal yang dekat dengaan ilmu. Sehubungan dengan hal tersebut, teks ialah bahasa yang bermanfat atau bahasa yang sementara melaksanakan pekerjaan tertentu pada tempat dan situasi. Mahsun (2014: 1) mengemukakan bahwa teks merupakan satuan bahasa yang berguna sebagai pengungkapan suatu bentuk tata dan cara sosial baik dengan lisan maupun tulisan dengan kaidah tertentu dengan secra lengkap.

\section{Teks Prosedur}

Mahsun (2014:30) mengemukakan bahwa teks prosedural ialah teks yang mempunyi tujuan untuk menyalurkan arah atau tuntunan tentang tata dan cara untuk membuat suatu hal yang telah ditentukan

Priyatni (2017 : 87) juga mengemukakan bahwa teks yang menyalurkan pedoman untuk mempergunakan bahasa sebagai penyampai pesan dengan langkah-langkah yang sistematis. 


\section{METODE PENELITIAN}

\section{Jenis Penelitian}

Jenis penelitian yang dipergunakan atau dipilih penulis dalam penelitian tersebut ialah deskriptif kualitatif atau biasa juga disebut dengn penelitian yang jauh dari angka-angka, dengan kata lain sehubungan dengan pendeskripsian kata-kata. Penelitian deskriptif kualitatif itu ialah penelitian sangat bertujuan untuk mendeksripsikan atau memaparkan secara utuh dan jelas pada suatu peristiwa atau kejadian tertentuyang berdasar pada kenyatan.

\section{Lokasi Penelitian}

Tempat Penelitian ini di sekolah SMP Negeri 1 Polewali yang berada pada $\mathrm{Jl}$. Hj. Andi Depu No.82, Lantora, Kecamatan Polewali, Kabupaten Polewali Mandar Sulawesi Barat

\section{Waktu Penelitian}

Pemgembilan data dilakukan pada hari senin,02 Maret 2020. Analisis data dilakukan mulai pada tanggal 05 Maret 2020 sampai pada tanggal 30 Mei 2020

\section{Subjek Penelitian}

Subjek dalam penelitian ini adalah peserta didik kelas VIIA SMP Negeri 1 Polewali. Jumlah keseluruhan peserta didik kelas VIIA SMP Negeri 1 Polewali adalah 30 orang, terdiri dari 14 laki-laki dan 16 perempuan.

\section{Variabel Penelitian}

Variabel penelitian ini adalah kemampuan menulis teks prosedur pada peserta didik kelas VII A SMP Negeri 1 Polewali.

\section{Defenisi Operasional Variabel}

Agar bisa mendapat gambaran-gambaran itu dengan mengenai variabel tertentu pada penelitian tersebut, maka ada pemaparan dengan mengenai pengertian pengoperasian variabel yaitu sebagai berikut:

a. Menulis ialah proses kreatif yang menggunakan berbagai lambang bahsa yang mengandung ide-ide yang akan disampaikan oleh pembicara itu sendiri ketika berhadpan dengan orang lain.

b. Teks prosedur merupakan teks yang berfungsi untuk memberi arahan atau petunjuk dan langkah yg harus dilaukam agar sesuatu pekerjaan dapat diterlaksana.

\section{Instrumen Penelitian}

Jenis instrumen penelitan yang akan di gunakan dalam penelitian ini adalah lembar tes yang dijadikan sebagai bahan dalam menjawab pertanyaan, lembar observasi, dan wawancara.

\section{Teknik Pengumpulan Data}

1. Teknik tes,dengan cara membagikan soal lembar tes kepada seorang siswa untuk membandingkan suatu objek yang berdasar pada aspek isi tulisan.

2. Teknik observasi,melakukan pengamatan secara la ngsung terhadap aktivitas siswa saat diberikan tes menulis teks prosedur.

3. Teknik wawancara, dengan cara mengajuhkan pertanyaan terhadap responden, yang berkaitan dengan pelajaran menulis teks prosedur.

4. Teknik dokumentasi, merekam situasi belajar berupa gambar yaitu dengan menggunakan kamera digital Gambar di ambil merupakan situasi pada saat pembelajaran di kelas dari awal hingga akhir pelajaran

\section{Teknik Analisis Data}

Teknik analisis data yang dipergunakan pada penelitian tersebut ialah teknik data kualitatif dn kuantitaf:

1. Teknik kualitatif dipergunakan untuk mencari data yng berupa lembr kertas observasi, pewawancaraan dan dokumentasi gmbar. Data tersebut adalah hasil dari pa yang kita dpatkan di lapangan dengan cara mendeskrsikan hasul pengamatan yang kemudian dikategorikan berdasar pada aspek-aspek yang diteliti. Sehubungan dengan hal itu, data itu berupa foto digunakan sebgai bukti nyata dari hasil penelitian kita.

2. Teknik kuantitatif dipergunakan untuk mencari kata atau biasa disebut juga dengan kualitatif Data kuantitatif diperoleh dari hasil tes seorang siswa yang telah diamati terhadap peserta didik yang berupa angka dengan menggunakan langkahlangkah sebagai berikut.

a. Mencari Nilai Rata-rata.

Untuk mendapat nilai rata-rata dari kemampuan menulis teks prosedur seorang siswa, maka digunakan rumus yang dikemukakan oleh Sugiyono (2011:76) yaitu:

$\bar{X}=\frac{\sum f x i}{\sum f i}$

Ket :

$\bar{X} \quad$ : Nilai rata-rata kelas

$\sum_{X i} \quad$ : Jumlah nilai hasil teks

$\sum f i \quad$ Jumalah siswa dalam kelas

b. Menghitung Persentase Kemampuan Siswa

Untuk menghitung persentase kemapuan siswa menulis teks prosedur maka digunakan rumus yang di kemukankan oleh Anas Sudijono (2011:43) yaitu :

$\mathrm{P}=\frac{f}{n} \times 100 \%$

Ket :

p : : Angka Persentase

f $\quad$ : Frekuensi yang sedang dicari persentasenya 
$\mathrm{n}$

: Number of case (jumlah frekuensi/ banyaknya individu)

100\% : Bilangan Tetap

\section{HASIL PENELITIAN DAN PEMBAHASAN}

\section{Penyajian Data Dittentukan Data Nontes}

Hasil ditentukan nontes, digunakan untuk mengetahui penjabaran kemampuan menulis teks prosedur yang terdiri dari observasi, wawancara, dan dokumentasi yang akan diuraikan sebagai berikut:

\section{a. Observasi}

Observasi yang dilakukan pada penelitian ini menghasilkan data kualitatif sebagai berikut.

Pada waktu kegiatan mengerjakan tugas menulis teks prosedur, mayoritas peserta didik dengan sungguh-sungguh dan begitu serius, apalagi pada saat peneliti memberikan arahan dalam mengerjakan tugas menulis teks prosedur. Pada saat proses megerjakan tugas sedang berlangsung peserta didik tidak ada yang ribut, peserta didik tidak ada yang meniru pekerjaan temanya, peserta didik kadang-kadang mengajukan pertanyaan jika ada hal-hal yang dianggap sulit dalam mengerjakan tugas tersebut, Namun dengan persiapan yang matang kegiatan tersebut dapat terlaksana dengan baik seperti yang diharapkan sehingga tidak heran nilainilai yang dicapai oleh peserta didik secara umum pun masuk dalam kategori baik atau mampu.

\section{b. Wawancara}

Wawancara dilakukan dalam bentuk tanya jawab yang berkaitan dengan pembelajaran menulis teks prosedur. Bentuk wawancara yang dilakukan setelah peserta didik selesai mengerjakan tugas menulis teks prosedur. Wawancara dilakukan pada 5 orang peserta didik berdasarkan rekomendasi dari guru mata pelajaran bahasa indonesia kelas VIIA dengan alasan bahwa ke 5 orang peserta didik ini mewakili siswa yang mampu dan kurang mampu atau dalam pelajaran bahasa indonesia.

Berdasarkan hasil wawawancara dari lima perwakilan peserta didik tersebut, dapat diketaui bahwa respon baik dilontarkan oleh 4 peserta didik, dari 2 peserta didik yang mendapatkan nilai sangat tiinggi dan 2 peserta didik yang mendapatkan nilai tinggi, dan respon yang kurang jelas dari 1 peserta didik yang mendapatkan nilai rendah. Kesulitan yang dihadapi peserta didik pada saat menulis teks prosedur adalah menyusun kata-kata atau kalimat atau bahasa tulis dan tata penulisan. Hal ini sesui dengan pernyataan oleh kelima peserta didik yang diwawancarai. Mereka mengemukakan bahwa dalam menulis teks prosedur hal yang yang paling sulit adalah pada struktur teks prosdur yaitu langkah-langkah penulisan teks prosedur pada bagian penyusunan kata-kata.

\section{Penyajian Data Ditentukan Data Tes}

Data hasil tes tersebut yang didapat dan dikasi kepada 30 seorang siswa juga telah dikerjakan unruk memperoleh nilai yang dijadikan pedoman untuk tahu kemampuan menulis teks prosedur peserta didik kelas VIIA SMP Negeri 1 Polewali. Dari hasil yang didapat dari data dengan secara keseluruhan didapat bahwa seorang siswa yang mampu dalam menulis teks prosedur berjumlah 28 orang atau 93,33\% dan siswa yang tidak mampu dalam menulis teks prosedur berjumlah 2 orang atau $6,67 \%$.

Dapat disimpulkan bahwa peserta didik kelas VIIA SMP Negeri 1 Polewali bisa menulis teks prosedur karena jumlah siswa tersebut mencapai 93,33\% siswa yang memperoleh nilai 75-100.

Pada penelitian tersebut juga digolongkan perolehan nilai seorang peserta didik yang berdasar pada keempat pedoman yang dinilai yaitu isi, struktur, kaidah penulisan, dan ciri kebahasaan. Berdasarkan isi terletak pada pengkategorian sangat bisa dengan nilai rata-rata 27,37. Berdasar pada struktur itu berada pada kategori sangat bisa dengan nilai rata-rata 19,07. Berdasar pada kaidah penulisan itu berada pada kategori bisa dengan nilai rata-rata 14,37. Berdasar pada ciri bahasa itu berada pada kategori bisa dengan nilai rata-rata 24,23 .

Adapun hasil analisis data pada penelitian tersebut secara semuanya telah menunjukkan kalau dari 30 peserta seorang siswa, nilai tertinggi yaitu 97 yang didapat 4 seorang siswa, sedang nilai yang rendah 61 yaitu 1 seorang peserta siswa.

\section{SIMPULAN}

Berdasarkan pada data yang diperoleh dari hasil penelitian tersebut, yaitu kemampuan menulis menulis teks prosedur pada peserta didik kelas VIIA SMP Negeri 1 Polewali Mandar dapat disimpulkan sebagai berikut:

Kemampuan menulis teks prosedur peserta didik kelas VIIA SMP Negeri 1 Polewali memperoleh nilai rata-rata 86,8 . Digambarkan bahwa peserta didik yang bisa atau mendapatkan nilai $75-100$ berjumlah 28 orang atau $93,33 \%$ dan siswa yang mendapatkan nilai 074 berjumlah 2 orang atau 6,67\%. Pada aspek isi, nilai rata-rata peserta didik berada pada kategori sangat mampu dengan nilai rata-rata 27,37. Pada aspek struktur berada dalam kategori sangat mampu dengan nilai 19,07. Pada aspek kaidah penulisan tersebut, nilai rata-rata peserta didik berada pada kategori mampu dengan nilai 13,37 dan pada aspek ciri kebahasaan, nilai rata-rata peserta didik berada pada kategori mampu dengan nilai 25,23.

Dapat disimpulkan bahwa peserta didik kelas VIIA SMP Negeri 1 Polewali mampu menulis teks 
prosedur karena jumlah peserta didik memcapai $75 \%$ yang memperoleh nilai 75-100.

\section{DAFTAR PUSTAKA}

Dalman. 2018. Keterampilan Menulis. Depok: PT Raja Grafindo Persada.

Djumigin, Sulastriningsih. 2011. Strategi dan Aplikasi Model Pembelajaran Inovatif Bahasa dan Sastra. Makassar: Badan Penerbit Universtas Negeri Makassar.

Haling, Abdul. 2007. Belajar dan Pembelajaran. Makassar: Badan Penerbit Universitas Negeri Makassar.

Kementrian Pendidikan dan Kebudayaan 2013. Informasi kurikulum 2013. Jakarta: Departemen Pendidikan dan Kebudayaan.

Kurnia, W. (2019). Efektivitas Pembelajaran Interaktif Berbasis Whatsapp Group Terhadap Kemampuan Menulis Teks Laporan Hasil Observasi. Celebes Education Review, 1(2), 105111.

Mahsun. 2014. Teks dalam Pembelajaran Bahasa Indonseia Kurikulum 2013. Jakarta Rajawali Pers.

Priyatni, Endah Tri. 2017. Desain Pembelajaran Bahasa Indonesia Dalam Kurikulum 2013. Jakarta: PT Bumi Aksara.

Rohima, Ima. 2014. BUPENA Bahasa Indonesia SMP/MTS Kelas VIII. Jakarta: Erlangga.

Sagala, Syaiful. 2009. Supervisi Pembelajaran. Bandung: Alfabeta.

Semi, M. Atar. 2007. Dasar-Dasar Keterampilan Menulis. Bandung: Angkasa.

Tarigan, Henry Guntur. 2008. Menulis Sebagai Suatu Keterampilan Berbahasa. Bandung: Angkasa.

Wahono, dkk. 2013. Mahir Berbahasa Indonesia untuk SMP/MTS Kelas VIII. Jakarta: Erlangga.

Sahabuddin, C., \& Basri, P. S. (2020, October). Factors Influencing Work Productivity of Community Health Center Employees. In 3rd International Conference on Education, Science, and Technology (ICEST 2019) (pp. 179-182). Atlantis Press.
Sahabuddin, C., Baharuddin, S. M., Farida, U., \& Yusriadi, Y. (2019). The Strategy of Community Empowerment for Bunggu Isolated Tribe in the Mamuju District. The Journal of Social Sciences Research, 5(4), 894-898.

Busrah, B. (2017). Pengaruh Labelisasi Halal dan Kualitas Layanan Terhadap Keputusan Pembelian Produk Makanan dalam Kemasan pada Mahasiswa FKIP Unasman (Doctoral dissertation, Universitas Islam Negeri Alauddin Makassar). 